\title{
Ethnomatematika: Budaya dalam Pembelajaran Matematika
}

\author{
Ririn Dwi Agustin"), Mika Ambarawati ${ }^{2)}$, Era Dewi Kartika ${ }^{3)}$ \\ 1,2,3) IKIP Budi Utomo Malang \\ Email: ririndwiagustin85@gmail.com
}

\begin{abstract}
The application of ethnomathematics-based cultural education that is integrated into learning can be through the development of learning instruments. Learning instruments consist of syllabus, learning material, student worksheets, learning resources, learning media, and evaluation tools. This studies discusses about worksheets, lesson plans, and syllabus in which ethnomatematics and character education have been included with purpose was to explain the development of syllabus, learning material, and mathematics student worksheets based on ethnomatematics in strengthening student character education.
\end{abstract}

Keyword: Cultural, Ethnomathematics

\begin{abstract}
ABSTRAK
Penerapan pendidikan budaya berbasis ethnomathematika yang diintegrasikan ke dalam pembelajaran dapat melalui pengembangan instrumen pembelajaran. Instrumen pembelajaran terdiri dari silabus, materi pembelajaran, lembar kerja siswa, sumber belajar, media pembelajaran, dan alat evaluasi. Kajian ini membahas tentang LKS, RPP, dan Silabus yang didalamnya sudah dimasukkan nilai etnomatematika dan pendidikan karakter dengan tujuan untuk menjelaskan pengembangan silabus, materi pembelajaran, dan matematika lembar kerja siswa berbasiskan etnomatematika dalam memperkuat pendidikan karakter siswa.
\end{abstract}

Kata Kunci: Budaya, Etnomatematika

\section{PENDAHULUAN}

Meskipun kita hidup dalam masyarakat yang didominasi oleh teknologi berbasis matematika, kebanyakan orang biasanya hanya memikirkan matematika disekolah ketika mereka berpikir tentang matematika. Masih banyak siswa yang masih membenci matematika atau percaya bahwa mereka tidak bisa matematika, seperti yang didefinisikan oleh (Mukhopadhay, Greer \& Roth, 2012). Faktanya, Wolfram (2010) menyatakan bahwa matematika berbasis teknologi di masa depan kemungkinan tidak lagi disebut "matematika" karena konotasinya yang negatif dan 
perubahan potensial pada kurikulum dan pedagogi. Alih-alih menanamkan ketakutan dan kebencian, pendidikan matematika harus menumbuhkan pemahaman yang lebih besar tentang bagaimana matematika diterapkan di dunia yang semakin maju teknologinya. Matematika sekolah perlu memperluas parameternya dan menjadi lebih inklusif untuk matematika di sekolah. Salah satu cara untuk melakukan ini adalah memasukkan aspek-aspek etnomatematika, matematika berbasis kultural, untuk membantu siswa mengembangkan minat yang lebih besar dalam matematika. Ketika minat mereka terhadap matematika tumbuh, para siswa akan berada dalam posisi yang lebih baik untuk melihat bahwa matematika melampaui ruang kelas, bahwa itu memiliki arti penting di dunia nyata.

Perubahan penting dalam pengajaran matematika perlu dilakukan untuk mengakomodasi perubahan berkelanjutan dan berkelanjutan dalam demografi siswa di kelas matematika. Beberapa ahli telah mengembangkan teori pedagogi yang relevan secara budaya yang meneliti proses belajar-mengajar dalam suatu paradigma kritis dan melalui hubungan eksplisit antara budaya siswa dan materi pelajaran sekolah (D'Ambrosio, 1990; Gay, 2000; Ladson-Billings, 1995). ; Rosa \& Orey, 2003). Dalam perspektif ini, perlu untuk mengintegrasikan kurikulum yang relevan secara budaya dalam kurikulum matematika yang ada. Menurut Torres-Velasquez dan Lobo (2004), perspektif ini merupakan komponen penting dari pendidikan budaya yang relevan karena mengusulkan bahwa guru mengkontekstualisasikan pembelajaran matematika dengan menghubungkan konten matematika dengan budaya dan pengalaman kehidupan nyata siswa.

Pedoman dari Dewan Nasional Guru Matematika (NCTM, 1991) menyoroti pentingnya membangun hubungan antara matematika dan kehidupan sehari-hari dan budaya siswa. Sesuai dengan pendekatan ini, Rosa dan Orey (2006) menegaskan bahwa "Ketika masalah praktis atau berbasis budaya diperiksa dalam konteks sosial yang tepat, matematika praktis kelompok sosial bukanlah hal yang sepele karena mereka mencerminkan tema yang sangat terkait dengan kehidupan sehari-hari. Menurut Rosa dan Orey (2008), kurikulum matematika yang relevan secara budaya harus fokus pada peran matematika dalam konteks sosiokultural yang melibatkan ide dan konsep yang terkait dengan ethnomatematika, menggunakan perspektif ethnomatematikal untuk memecahkan masalah kontekstual. 
Kurikulum matematika semacam ini menguji kesesuaian budaya antara kelompok siswa dan sekolah, yang menunjukkan rasa hormat guru terhadap pengalaman budaya siswa mereka. Menurut Zeichner (1996), agar guru dapat menerapkan prinsip kesesuaian budaya, mereka harus memiliki pengetahuan dan penghormatan terhadap berbagai tradisi budaya dan bahasa siswa di kelas mereka. Dengan demikian, mereka harus mengembangkan rasa yang jelas dari identitas etnis dan budaya mereka sendiri untuk dapat memahami dan menghargai mereka dari siswa mereka untuk memahami matematika sebagai disiplin yang dibangun secara sosial dan budaya (Banks, 1991; Lee, 1999). Dengan demikian, guru perlu memahami apa yang dianggap sebagai pengetahuan dalam matematika serta bagaimana pengetahuan mungkin terkait dengan norma-norma dan nilai-nilai dari beragam budaya. Dengan kata lain, berurusan dengan pengintegrasian beragam budaya di kelas memerlukan kerangka kerja konseptual untuk membuat keputusan pedagogi koheren sebagai guru, yang dapat membantu mereka memahami bagaimana bias budaya mereka memengaruhi penilaian tentang kinerja siswa dan menghalangi kemampuan mereka untuk belajar matematika.

\section{HASIL DAN PEMBAHASAN}

Matematika telah menjadi bagian dari kebudayaan manusia sudah sangat lama. Di mulai dari jaman pra sejarah, jaman bangsa Mesir kuno, bangsa Yunani, bangsa India, bangsa Cina, bangsa Romawi, hingga bangsa Eropa di masa kini. Kreasi manusia dalam bentuk kebudayaan terwujud dalam bentuk gagasan, aktivitas maupun artefak. Nilai-nilai yang tersimpan dalam perilaku budaya manusia menunjukkan daya rasa estetis dan daya kreasi manusia. Integrasi antara matematika dan budaya dalam bentuk yang kontekstual dan realistik. Matematika sebagai bagian dari kebudayaan dapat diterapkan dan digunakan untuk menganalisis hal-hal yang sifatnya inovatif. Jadi, matematika dapat digunakan sebagai alat untuk mengembangkan budaya yang unggul. Selain itu, usaha untuk menyelesaikan permasalahan yang timbul, sadar atau tidak manusia telah menggunakan matematika. Begitu juga dalam pola hidup suatu komunitas masyarakat dalam mempertahankan kebudayaannnya, dimungkinkan komunitas masyarakat tersebut menggunakan ideide matematis. Ide-ide matematis dalam konteks kegiatan budaya mulai dipandang oleh para ahli pendidikan matematika sebagai suatu hal yang penting (zulfikli, 2017).

Salah satu yang dapat menjembatani antara budaya dan pendidikan adalah etnomatematika. Etnomatematika adalah bentuk matematika yang dipengaruhi atau 
didasarkan budaya. Melalui penerapan etnomatematika dalam pendidikan khususnya pendidikan matematika diharapakan nantinya peserta didik dapat lebih memahami matematika, dan lebih memahami budaya mereka, dan nantinya para pendidik lebih mudah untuk menanamkan nilai budaya itu sendiri dalam diri peserta didik, sehingga nilai budaya yang merupakan bagian karakter bangsa tertanam sejak dini dalam diri peserta didik.

Penanaman nilai budaya dalam pendidikan dapat dijembati dengan etnomatematika. Etnomatematika sebagai suatu pendidikan matematika yang mengintegrasikan nilai-nilai kultur dalam pembelajaran matematika perlu menggagas integrasi secara nyata nilai-nilai kultur tersebut (Sirate, 2015).

\section{Etnomatematika}

Etnomatematika adalah bentuk matematika yang dipengaruhi atau didasarkan budaya. Salah satu pendekatan yang dapat memberikan kesempatan kepada siswa dalam meningkatkan kemampuan komunikasi matematis adalah pembelajara kontruktivisme serta pembelajaran berbasis budaya (Wahyuni: 2013). Representasi kompleks dan dinamis yang menggambarkan pengaruh kultural penggunaan matematika dalam aplikasinya merupakan etnomatematika. Pada pembelajaran berbasis etnomatematika, siswa dituntut untuk memahami budaya yang ada di sekitar daerah mereka terkait materi yang akan diajarkan oleh guru (Hartoyo, 2012: 15).

Selain itu, model pembelajaran etnomatematika digunakan untuk mengaitkan antara pengetahuan yang telah dimiliki siswa dengan pemahaman siswa pada situasi di lingkungan setempatnya (Ismawanto: 2014). Dengan demikian, etnomatematika adalah implementasi budaya dalam pembelajaran matematika.

\section{Model Kurikulum Etnomatematika}

Gagasan etnomatematika dalam pembelajaran matematika dan dalam kurikulum sekolah memberi nuansa baru dalam pengajaran matematika di sekolah dengan pertimbangan bahwa bangsa indonesia terdiri atas berbagai suku dan budaya. Model kurikulum etnomatematika harus (a) dirancang dalam konteks yang sesuai dan berarti, (b) dalam bentuk conten atau isi budaya khusus yang berbeda dengan konsep matematika umumnya seperti yang diajarkan di kebanyakan sekolah, (c) membangun ide bahwa etnomatematika berada dalam bidang pendidikan, (d) 
menjadi bagian ide matematika yang membawa kelas dalam konteks budaya, dan (e) merupakan integrasi konsep dan praktik matematika ke dalam budaya siswa yang dapat menjadi bagian dari pendidikan amtematika formal (Sirate, 2015). Dengan demikian, model kurikulum etnomatematika merupakan gagasan kurikulum dalam konteks budaya. Pengaplikasian kurikulum dengan adanya konteks budaya di dalamnya tentu dengan penambahan pendidikan karakter yang sangat penting dalam kurikulum 2013.

Pendidikan karakter adalah sebuah proses pemberian tuntunan kepada peserta didik untuk menjadi manusia seutuhnya yang berkarakter dalam dimensi hati, pikir, raga, serta karsa (Muchlas: 2011). Tujuan pembentukan karakter menghendaki adanya perubahan tingkah laku, sikap, dan kepribadian pada siswa. Secara operasional tujuan pendidikan karakter menurut Wiyani (2013) di sekolah sebagai berikut:

a. Menguatkan dan mengembangkan nilai-nilai kehidupan yang dianggap penting dan perlu sehingga menjadi kepribadian kepemilikan peserta didik yang khas sebagaimana nilai-nilai yang dikembangkan. Tujuannya adalah memfasilitasi penguatan dan pengembangan nilai-nilai tertentu sehingga terwujud dalam perilaku anak, baik pada saat masih sekolah maupun setelah lulus.

b. Mengoreksi perilaku peserta didik yang tidak bersesuaian dengan nilai-nilai yang dikembangkan oleh sekolah. Tujuan ini memiliki makna bahwa tujuan pendidikan karakter memiliki sasaran untuk meluruskan berbagai perilaku negatif anak menjadi positif.

c. Membangun koneksi yang harmoni dengan keluarga dan masyarakat dalam memerankan tanggung jawab karakter bersama. Tujuan ini bermakna bahwa karakter di sekolah harus dihubungkan dengan proses pendidikan di keluarga.

Dengan demikian, pembelajaran berbasis pendidikan karakter akan membentuk sikap dan kepribadian siswa yang bertanggung jawab. Selain itu, pendidikan karakter harus mulai diterapkan di lingkungan sekolah, keluarga, dan masyarakat.

\section{Etnomatematika dalam Praktik Pembelajaran Matematika}

Etnomatematika untuk membentuk karakter bangsa agar lebih optimal maka dapat diintegrasikan dalam pembelajaran. Hal ini memperkuat perkembangan kemampuan berpikir siswa secara konkrit, integratif, dan hierarkis. Dalam 
pembelajaran dibutuhkan perangkat pembelajaran matematika yang mengandung etnomatematika.

Keberhasilan seorang guru dalam proses pembelajaran merupakan suatu kewajiban. Oleh sebab itu, dibutuhkan persiapan yang matang pada perangkat pembelajaran. Perangkat pembelajaran adalah sejumlah bahan, alat, media, petunjuk, dan pedoman yang akan digunakan dalam proses pembelajaran (Suhadi, 2007: 24). Adapun perangkat pembelajaran yang akan dikembangkan adalah silabus, RPP, dan LKS.

Silabus merupakan rencana Pembelajaran pada mata pelajaran atau tema tertentu dalam pelaksanaan kurikulum. Umumnya silabus memiliki komponenkomponen sebagai berikut: (1) kompetensi inti; (2) kompetensi dasar;(3) materi pembelajaran; (4) kegiatan pembelajaran; (5) penilaian; (6) alokasi waktu; dan (7) sumber belajar.

Rencana pelaksanaan pembelajaran merupakan panduan kegiatan guru dalam kegiatan guru dalam kegiatan pembelajaran sekaligus uraian kegiatan siswa yang berhubungan dengan kegiatan guru yang dimaksudkan. RPP ini disusun berdasarkan indikator-indikator yang telah disusun mengacu pada prinsip dan karakteristik pembelajaran yang dipilih berisi tujuan pembelajaran, materi ajar, metode pengajaran, sumber belajar, dan penilaian hasil belajar, RPP yang disusun mencakup alokasi waktu 2 x 40 menit (SMP) untuk setiap pertemuan (Suhadi, 2007:24).

Lembar kerja siswa adalah panduan siswa yang digunakan untuk melakukan kegiatan penyelidikan atau pemecahan masalah. Lembar kegiatan ini berupa panduan untuk latihan pengembangan aspek kognitif maupun panduan untuk pengembangan semua aspek pembelajaran dalam bentuk panduan eksperimen atau demonstrasi (Trianto, 2007). Langkah-langkah persiapan LKS dijelaskan dalam depdiknas (2008) sebagai berikut: 1) analisis kurikulum yang dilakukan dengan memperhatikan materi pokok, pengalaman belajar siswa, dan kompetensi yang harus dicapai siswa, 2) menyusun peta kebutuhan LKS yang berguna untuk mengetahui jumlah kebutuhan LKS dan urutan LKS, 3) menentukan judul-judul LKS yang harus sesuai dengan KD, materi pokok, dan pengalaman belajar, 4) Penulisan LKS yaitu: (a) perumusan KD yang harus dikuasai, (b) menentukan alat penilaian, (c) penyusunan materi dari 
berbagai sumber, (d) memperhatikan struktur LKS yang meliputi: (1) judul, (2) petunjuk belajar, (3) kompetensi yang akan dicapai, (4) informasi pedukung, (5) tugas dan langkah-langkah kerja, dan (6) penilaian.

\section{KESIMPULAN DAN SARAN}

Penerapan pendidikan budaya berbasis ethnomathematika yang diintegrasikan ke dalam pembelajaran dapat melalui pengembangan instrumen pembelajaran. Instrumen pembelajaran terdiri dari silabus, materi pembelajaran, lembar kerja siswa, sumber belajar, media pembelajaran, dan alat evaluasi. Kajian ini membahas tentang LKS, RPP, dan Silabus yang didalamnya sudah dimasukkan nilai etnomatematika dan pendidikan karakter dengan tujuan untuk menjelaskan pengembangan silabus, materi pembelajaran, dan matematika lembar kerja siswa berbasiskan etnomatematika dalam memperkuat pendidikan karakter siswa.

Saran yang dapat disampaikan pembahasan diatas adalah, yaitu: (1) pengaplikasian lebih lanjut seluruh perangkat pembelajaran dalam kelas, (2) adanya analisis lebih lanjut terkait pengaplikasian seluruh perangkat, (3) adanya pengembangan perangkat dan media berbasis ethnomatematika yang memperkuat karakter siswa.

\section{REFERENSI}

Astri, dkk. 2013. Peran Etnomatematika Dalam Membangun Karakter Bangsa. Seminar Nasional Matematika dan Pendidikan Matematika FMIPA UNY. Yogyakarta (9 November 2013).

Hartoyo, A. 2012. Eksplorasi Etnomatematika pada Budaya Masyarakat Dayak Perbatasan Indonesia-Malaysia Kabupaten Sanggau Kalbar. Jurnal Penelitian Pendidikan, 13(1): 14-23. Tersedia di http://jurnal.upi.edu/file/3agung.pdf [diakses 10-01-2015].

Herutomo, R.A.(2015).Intregasi Nilai-nilai Budaya Bangsa dalam Pembelajaran Matematika.

(Online) http:www.slideshare.net/rezkyagungherutomo/integrasi-nilai-budaya-padapembelajaran-matematika-44247660 (diakses 01 Oktober 2018)

Ismawanto. 2014. Pengembangan Cd Interaktif Berbantuan Swishmax Dengan Model Etnomatematika Pada Materi Bangun Ruang Sisi Datar Kelas VIII 
Semester II. Prosiding ISBN: 978-602-0960-00-5. Mathematics and Sciences Forum.

Muchlas dkk. 2011. Konsep dan Model Pendidikan Karakter. Bandung: Remaja Rosdakarya.

Sirate, S. F. S. 2015. Menggagas Integrasi Multikultur Pembelajaran Matematika. Auladuna, Vol.2, No.2, Hal: 246-263.

Trianto. 2007. Model Pembelajaran Terpadu dalam Teori dan Praktek. Surabaya: Prestasi Pustaka.

Wahyuni, A., dkk. 2013. Peran Etnomatematika dalam Membangun Karakter Bangsa. Prosiding ISBN : 978-979-16353-9-4. Makalah dipresentasikan dalam Seminar nasional Matematika dan Pendidikan Matematika dengan tema "Penguatan Peran Matematika dan Pendidikan Matematika untuk Indonesia yang Lebih Baik" pada tanggal 9 November 2013 di Jurusan pendidikan Matematika FMIPA.

Wiyani, A.N. 2013. Membuminya Pendidikan Karakter di SD: Konsep, Praktek, dan Strategi. Jakarta. Ar-Ruzz Media.

Zulkifli, M.Nuh dan Dardiri. (2017). Etnomatematika dalam Sistem Pembilangan Pada Masyarakat Melayu Riau. Jurnal Penelitian sosial keagamaan,Vol.19, No.2.ejournal.uin-

suska.ac.id/index.php/Kutubkhanah/article/download/2552/1616 